23. Trudy XXX syezda gornopromyshlennikov Yuga Rossii [Proceedings of the XXX Congress of Miners of the South of Russia]. (1906). T. II. Kharkov: T-vo «Pechatnia S. P. Yakovleva».

24. Trudy XXXVII syezda gornopromyshlennikov Yuga Rossii [Proceedings of the XXXVII Congress of Miners of the South of Russia]. (1913). T. 1. Kharkov : Tip. B. Bengis.

25. Fomin, P. I. (1920). Donetskiy basseyn [Donetsk coal field]. Kharkov : B. i.

26. Fomin, P. I. (1924). Gornaya i gornozavodskaya promyshlennost Yuga Rossii [Mining and metallurgical industries of the South of Russia]. T. II. Kharkov : «Khoziaystvo Donbassa».

27. Fomin, P. I. (1908). Kratkiy ocherk istorii syezdov gornopromyshlennikov Yuga Rossii [A Short Essay of the History of Congresses of Mine-Industrialists on the South of Russia]. Kharkov : Tip. i Litogr. M. Zilberberg i S-vya.

28. Khronika [Chronicle]. (1910). Promyshlennost i tirgovlia, 24, 668.

29. Chernomorsko-Baltiyskiy vodnyu put [Black Sea-Baltic Waterway]. (1911). Gorno-zavodskoe delo, 35, 2700-2702.

30. Chernyshev, B. (1912). Chernomorsko-Baltiyskiy vodnyu put v finansovoekonomicheskom osveshchenii [Black Sea-Baltic Waterway in Financial and Economic Presentation]. Russkoye sudokhodstvo, 9, 35-39.

31. Chernyshev, B. (1912). Chernomorsko-Baltiyskiy vodnyu put v finansovoekonomicheskom osveshchenii [Black Sea-Baltic Waterway in Financial and Economic Presentation]. Russkoye sudokhodstvo, 11, 23-29.

32. Shliakhov, O. B. (2003). Sudnovlasnyky i moriaky Azovo-Chornomorskogo baseinu: 90-ti rr. XIX st. - 1914 r.: monografiia [Ship-Owners and Seamen of the Azov-Black Sea Basin: 90-th Years of the 19-th Century - 1914: Monograph]. Dnipropetrovsk : Vyd-vo Dnipropetr. un-tu.

УДК 94(47+57): 323.281-055.2

\title{
ДОСВІД ВИЖИВАННЯ ЖІНОК В АКМОЛІНСЬКОМУ ТАБОРІ ДЛЯ ДРУЖИН ЗРАДНИКІВ БАТЬКІВЩИНИ (НА ОСНОВІ ЕГО-СВІДЧЕНЬ)
}

\section{Омельченко Поліна}

Основним завданням автора є спроба показати специифічність повсякдення жінок-увя'знених Акмолінського табору для дружин «зрадників Батьківщини», закцентувавши увагу на способах виживання арештанток $i$ на формах подолань горя в таборі. В основі методологічної бази дослідження - загальнонаукові принциипи аналізу та синтезу, метод критичного аналізу джерел, методологія повсякденної історії, а також 
методика роботи з едо-документами. У пропонованій статті дослідником було використано антропочентричний підхід, згідно з яким иентральним об'єктом вивчення є людина, а також гендерний підхід для аналізу власне жіночого виміру повсякденного життя в таборах.

Акмолінський табір відрізнявся не лише від виправно-трудових таборів системи ГУЛАГу, але й від собі подібних. Жінки мали там свою систему иінностей та по-іншому намагалися вижити за колючим дротом. Витримати своє засудження їм допомогала щчоденна прачя та віра в майбутнє, найголовніше - у якнайскоріше звільнення. Аби пережити горе від втрати родини, своїх близьких, жінкам допомагала творчість та дружба між собою.

Результати та висновки аналізованої проблеми в подальшому можуть бути використані для порівняння повсякденного життя жінок у різний період існування виправно-трудової системи, стануть корисними для глибшого аналізу таборового досвіду украӥнок. Загалом розширення та подальший аналіз названої теми є важливим для формування в Україні історичної пам'яті та подолання тоталітарного минулого.

Ключові слова: ГУЛАГ, жіноча історія, історія повсякдення, член сім' $і$ «зрадника Батьківщчини», «ворог народу», Акмолінський табір для дружин зрадників Батьківщини.

Сталінські репресії є однією з найтрагічніших сторінок історії СРСР. Для сучасної демократичної країни, якою є Україна, вагомим є розширення поля історичної пам'яті за допомогою раніше замовчуваної інформації щодо репресивної політики радянського керівництва. Також, поза сумнівом, це $\epsilon$ важливим у процесі виховання в теперішніх та майбутніх громадянах нашої країни поваги до пращурів, які стали жертвами історичної трагедії.

Дослідження історії повсякдення $є$ однією 3 ознак гуманізації та демократизації історіографічного дискурсу. Для пострадянських країн ця тематика $є$ однією 3 маловивчених i потребує аналізу й засвоєння напрацьованої на Заході теорії та методології, бо використання іiї оптики та інструментарію в пізнанні радянського тоталітаризму є вкрай необхідним. Безпосередньо жіночий вимір історії повсякдення $\epsilon$ цінним для розвитку жіночих студій у сучасній Україні, вивчення яких $є$ досить актуальним на сьогодні.

Загалом, жінка в таборах ГУЛАГу $є$ особливою темою наукових пошуків. ГУЛАГ здебільшого привертає увагу дослідників у контексті злочинів і репресій сталінського режиму, а також його економічного потенціалу. Дослідження повсякденного життя в таборах не є популярним серед сучасних науковців. Здебільшого, історики звертаються до табірного досвіду, не розглядаючи окремо жіночий.

Пропонована проблематика в сучасній українській науці $\epsilon$ малодослідженою. Важливим доробком із вивчення цього питання є праця 
української дослідниці Тамари Вронської: «Упокорення страхом: сімейне заручництво у каральній політиці радянської влади» [5]. У названій монографії науковець подала кількісну характеристику засуджених жінок, яких було репресовано як члена родини «зрадника Батьківщини». Дослідниця також висвітлила умови утримання жінок у таборах. Проте інші аспекти повсякденного життя в названій роботі не проаналізовано.

Важливим дослідженням жіночого повсякдення у ГУЛАГу є праця Оксани Кісь «Українки в ГУЛАГу: вижити значить перемогти» [15]. Автор вивчила особисті спогади колишніх невільниць та офіційні документи, на основі яких висвітлила різні сторони табірного досвіду українських жінок.

Загалом окремих дослідницьких робіт про табори такого особливого типу як Акмолінське спецвідділення немає. Фрагментарно цієї теми торкається праця Галини Іванової «Історія ГУЛАГу 1918-1958: соціальноекономічний і політико-правовий аспект» [12], а також автори Галина Салтик [28], Олександр Даніель та Арсеній Рогінський [26], Світлана Єлеуханова [11]. Важливим науковим доробком, який надає загальну інформацію про систему ГУЛАГ ( $\epsilon$ необхідним для порівняння повсякденного життя Акмолінського табору з іншими жіночими таборами), є праця Енн Епллбом «ГУЛАГ. Павутиння великого терору» [33], а також художньо-історичне дослідження Олександра Солженіцина «Архіпелаг ГУЛАГ» [30].

У системі ГУЛАГу, яка мала специфічний устрій, таборів такого особливого типу як Акмолінський табір дружин зрадників Батьківщини (далі - «АЛЖИР»: від російського - Акмолинский лагерь жен изменников Родины) було лише два: Темніківський виправно-трудовий табір (Мордовська АРСР) та спецвідділення біля м. Томськ (Новосибірська область РРФСР). Усі вони були призначені для ув'язнення лише за «політичні злочини», а конкретно за те, що жінка була членом сім’ї «зрадника Батьківщини». В АЛЖИРі склалося повсякденне життя, відмінне від інших таборів системи різних режимів і типів. Жінки мали свій табірний простір, який характеризувався специфічним побутом, розвагами, способами виживання: простір, у якому була велика кількість радянської інтелігенції жіночої статі, яких відірвали від своєї родини та від нормального життя.

Пропонована розвідка має на меті показати специфічність повсякденності жінок Акмолінського табору для дружин зрадників Батьківщини, розглянувши такі аспекти таборового досвіду арештантів, як форми боротьби жінок із горем і способи виживання у таборі.

Щоб проаналізувати буденність жінок-ув'язнених Акмолінського спецвідділення, було використано надруковані спогади його колишніх арештантів. Деякі з названих спогадів написані дітьми колишніх ув'язнених із розповідей їхніх матерів. Також основою стали листи, які відправляли жінки 3 табору до своїх рідних. Усі подані спогади жінок розповідають про період від 1938 до 1941 р., бо саме в цей період АЛЖИР був спецвідділенням і відрізнявся від інших жіночих таборів. Це основний принцип, згідно з яким 
обиралися джерела. У ході розгляду дослідницької проблеми також було задіяно документальний фільм Дарини Віоліної «Ми будемо жити» (реж. Сергій Павловський), що містить інформацію для аналізу поставлених перед нашою розвідкою завдань [23].

Для глибшого вивчення та розуміння специфіки повсякденного життя Акмолінського табору в роботі також були використані спогади жінокарештантів інших спеціальних таборів, призначених для дружин «ворогів народу» (Темніківського виправно-трудового табору та спецвідділення біля м. Томськ). Ці матеріали $є$ цінними як джерело, що доведе специфічність такого типу таборів ГУЛАГу, які не були схожими на інші жіночі табори системи. Бо, по-перше, жінки перебували окремо від чоловічої половини табору. У змішаних таборах становище жінки здебільщого було жахливим через сексуальний тиск із боку чоловіків. У таких таборах у більшості випадків, щоб вижити, треба було обирати собі «табірного чоловіка», який би тебе захищав і навіть годував. Життя в таких таборах калічило жінку морально та фізично, бо іiі гордість, права, достоїнства були повністю стерті $[9,30]$. По-друге, на окремих жіночих табірних пунктах, де відбували покарання не лише жінки, засуджені за «політичними статтями», а також і «жіночий криміналітет», створювався нежіночний жорстокий загальний норов: «постійна матірщина, постійний бій, інакше не виживеш...» $[30,151]$. Жінкам постійно доводилося спостерігати аморальну поведінку «соціальноблизьких» арештантів. Також спогади ув'язнаниех із інших таборів, призначених для членів родин «зрадника Батьківщини» дають змогу побачити, що АЛЖИР, попри свою схожість 3 іншими жіночими спецтаборами для членів сімей «зрадників Батьківщини», відрізнявся від них і мав свої особливості. Для точнішого розуміння проблеми у праці також використано спогади арештанток із таборів звичайного режиму змішаного типу.

АЛЖИР було відкрито на початку 1938 р., він розташовувався на території Казахської РСР, ставши частиною великого Карагандинського виправно-трудового табору (далі - КАРЛАГ: від російського «Карагандинский исправительно-трудовой лагерь»), хоча територіально перебував за його межами $[11,8]$. Табір вважали спеціальним відділенням КАРЛАГу $[11,8]$. У системі ГУЛАГу «спеціальне відділення» чи «спецтабір» означало повну ізоляцію арештантів від зовнішного світу, а також жорсткий режим перебування в таборі, адже в них мешкали особливо небезпечні злочинці (засуджені за «політичні злочини» та кримінальники-рецидивісти). Тобто АЛЖИР було створено спеціально для «найбільш небезпечних» дружин «зрадників Батьківщини» [26].

Потрапляючи до АЛЖИРу, жінки, у переважній більшості, продовжували усвідомлювати себе відповідальними перед Батьківщиною. Навіть у неволі вони все ж залишалися відданими партії та радянській ідеології. Свідомість жінок була настільки «радянська», що вони більшу частину свого ув'язнення були впевнені, що керівництво держави не причетне до їхнього 
арешту. Маріанна Анцис писала у своїх спогадах: «Потрібно було, перебуваючи у статусі арештанток, зібрати усю свою волю, усі свої думки, спираючись на наявний досвід праці та знань, які отримали у партії, думати про організацію в степу нового життя, організацію праці, щоб продовжувати жити та праџювати як радянські люди, як комуністи» [2].

Жінки не розуміли, чому й за що вони арештовані й ув'язнені. Лише 3 плином часу кожна усвідомлювала, що «сидить за чоловіка», що конкретної провини власне за нею немає. Але й причин арешту чоловіків жінки не могли зрозуміти. Вони були впевнені у їхній невинності, бо більшість чоловіків були віддані державі, партії та вождю. Клавдія Бабаєва пам'ятає, що іiі чоловік був великим прихильником Сталіна, по-справжньому відданим йому [23]. Фанні Кривицька весь час доводила, що: «У нас в Радянському Союзі такого бути не може. Він ні в чому не винен» $[14,91]$. Ось що згадує ще одна колишня арештантка: «Всі ми розуміли, щзо заарештовані по чиійсь злій волі, що наші чоловіки, так само як $і$ ми, ні в чому не винні» [31, 37]. Як пам'ятає Клавдія Каледіна: «Я ні одного разу не чула, шөоб хтось із дружин засумнівалася у своєму чоловікові, подумала, щзо він справді зрадник» [10, 182].

Попри все це, спантеличені арештантки були впевнені, що незабаром все стане на свої місця і настане справедливість $[17,22]$. За словами Есфіль Славіної, більшість жінок у таборі були переконаними «сталіністками», дружинами партійних працівників, відповідальних і завзятих комуністівробітників [29]. Можливо, тому жінки всеодно продовжували вірити партії. Ольга Кучумова згадує, що для неї найдивнішим було те, що ніхто не піднявся протестувати - настільки безглуздо й нереально все це виглядало [19]. Виявом протесту дружини «ворогів народу» були листи до влади. Як приклад, листи ув'язненої Валентини Зей-Онищенко, написані 19 листопада 1939 р. до наркома внутрішніх справ і прокурора СРСР, у якому вона переконувала, що є відданою своїй Батьківщині й надалі буде доводити це, а також аргументувала своє прохання звільнити іiі $[5,194]$.

Жінки в АЛЖИРі по-різному сприймали щоденну працю. Спільним у них було те, що ставилися вони до неї «відповідально», якої б важкості вона не була. Більшість жінок у таборі працювали на повну силу. Колишня ув'язнена згадувала, що працівники табору називали їх «святими жінками» $[13,42]$. Згідно зі спогадами однієї з колишніх жінок-в'язнів, у Акмолінському таборі був дружній і працьовитий колектив $[17,20]$. Таке завзяття до роботи дивувало табірне керівництво. Співробітники табору, які раніше здебільшого мали справу 3 кримінальним жіночим світом, дивувалися смиренності та працелюбності арештанток АЛЖИРу $[13,42]$. Лідія Віоліна зазначає, що своєю відданою працею жінки створили з табору «оазис» серед казахстанського степу [23].

Більшість «алжирок» у праці бачили своє спасіння не так фізичне, як моральне [2]. Варвара Курошева пам'ятає, що праця відволікала від того, 
щоб не зійти з розуму від одного лише усвідомлення того, що ти - член сім’ «зрадника Батьківщини» [23].

Деякі жінки були переконані, що плідна праця допоможе їм швидше відбути термін ув'язнення. «Праці віддавалися повністю, тому що вважали, що якщо будемо день і ніч працювати нас скоріше відпустять додому»,писала колишня ув'язнена [23]. Але більшість жінок бачили в праці моральне спасіння, а саме: спосіб відволіктися від суму за родиною та втраченими дітьми. Галина Колдомасова писала, що виходячи за зону вона раділа, що праця допоможе їй відволіктися від материнського горя $[17,19]$.

Проте, не всім жінкам робота допомагала відкинути думки про родину. Клавдія Швер згадує: «Працювали 3 остервенінням... Хотілося забутися... Але це було неможливо! Що б я не робила переді мною, як живі, стояли мої діти» $[10,182]$.

Цікаво, що відповідальне ставлення до праці сприймалося деякими жінками як своєрідний подружній обов'язок перед чоловіком. Колишня арештантка зазначає у своїх спогадах: «Ні одна з ув’язнених не відмовилась від праці, ні одна не втекла за вісім років арешту... Інакше ми б образили пам'ять своїх чоловіків» [10, 182].

Як і в інших таборах системи ГУЛАГ, в АЛЖИРі щоденна праця була одним із найголовніших аспектів повсякденного життя арештантів, тому займала більшу частину часу життя жінок у таборі.

У Акмолінському таборі було, по-перше, багато роботи, по-друге, вона була різного виду. Ув'язнені самі будували їдальні, котельні та лазні [22, 78]. Більше того, вони добудовували бараки 3 саману (будівельний стіновий матеріал, що є цеглою з суміші глини, соломи та піску) [31, 34]. Також табір мав господарську частину, цехи вишивання, швацькі, а також городнє господарство $[4,120]$. Звичайно, в Акмолінському таборі були й загальні роботи, які, як і всюди у ГУЛАЗі, називали каторжними (жінки самостійно робили самани, працювали на цегляному заводі, розвантажували вагони та інше).

У таборі такого ж типу, як і Акмолінський, у Потьмі (Мордовська APCP), жінки працювали лише в гаптувальному та швацькому цеху [14, 93]. Можна вважати, що «алжиркам» насправді «пощастило», що в таборі було багато різноманітної роботи. Вони могли себе чимось зайняти та відволіктися від сумних думок. Для прикладу, у таборі для дружин «ворогів народу», біля м. Томськ, згідно зі спогадами однієї 3 колишніх ув'язнених, жінки страждали від того, що не могли себе нічим зайняти й тому було важче відволікатися від суму, бо в таборі на початку його заснування не було роботи $[20,15]$.

У деяких випадках відповідальне ставлення до праці допомагало вижити саме фізично. Колишня ув'язнена Аіза Рискулова, яку начальник КАРЛАГу відзначав як «виключно добросовісну, акуратну, завдяки якій перевиконувались плани по тваринництву», обіймала посаду ветеринарного лікаря й під 
час забою худоби крала м'ясо, потім варила його і передавала голодним жінкам у табір $[27,226]$. Також деякі відповідальні працівниці табору мали офіційні табірні привілеї. Такі категорії арештантів як керівники швацьких фабрик, лікарі, завідувачі різними табірними відділами не жили в загальних бараках, вони мали невеликі будиночки всередині зони, а також мали окремі столи в їдальні $[25,92]$. Але про такі привілеї можна говорити лише з 1939 р., оскільки увесь 1938 р. жінки працювали над забудовою табору.

Загалом праця для жінок-ув'язнених ГУЛАГу (не беручи до уваги «соціально-близьких» жінок, тобто зі світу «криміналітету») відігравала надзвичайно важливу роль. Усупереч тому, що в більшості випадків вона була дуже важкою, як для жінки, а також здебільшого була докорінно відмінною від тією, якою жінки займалися на волі, праця все ж таки сприймалася як згадка про життя на волі. Ольга Адамова-Слизорберг, яка відбувала арешт у Магадані, згадує: «Праця була єдиним людським, що нам залишалося. У нас не було родини, не було книг, газет, ми жили в бруді, темряві, смороді, в жіночому бараці була постійна лайка. Ми витримували приниження. Праця була людяною та чистою ... єдиний світлий спогад у темряві табірного життя» $[1,101,102]$.

Олександр Солженіцин зазначав, що жінки в таборах пограбовані у всьому, що наповнює жіноче i, взагалі, людське життя: родина, материнство, дружнє оточення $[30,154]$. Але багато жінок, які пройшли табори, впевнені, що стать давала їм «привілеї» перед чоловіками [33, 294]. Енн Епплбом вважає, що в жінок виникали міцні дружні відносини, вони надавали одна одній таку допомогу, на яку чоловіки рідко були спроможні [33, 294]. Проаналізувавши спогади «алжирок», можна стверджувати, що дружба була однією 3 тих складових табірного життя, які допомагали жінкам витримати перебування у ГУЛАГу як морально, так і фізично. Пов'язані спільним горем, жінки тяглися одна до одної. У вільний час від вечері до відбою, часто i далеко за північ, ув'язнені ділилися своїми переживаннями і думками $[25,75]$. Ольга Кучумова впевнена, що саме загальна біда зблизила жінокарештантів [19]. Маріанна Анцис пам'ятає, що, коли ув'язнені вперше почали працювати 3 очеретом, їх охопив відчай: «Але кожна 3 нас, відчуваючи присутність ліктя товариша, поступово відганяла від себе страх і праця здавалася легшою» [2]. Морально сильніші жінки намагалися допомагати слабшим. У своїх спогадах Ольга Кучумова писала, що спочатку вона була у відчаї, але згодом стала втішати своїх подруг і себе, розповідати вірші, щоб відволікти жінок від усього табірного, що їх оточує [19].

У закритому просторі табору жінки постійно спілкувалися $[25,5]$. У АЛЖИРі відбували покарання жінки-арештанти різної національності, різного характеру та з різним минулим. За словами однієї з ув'язнених, у таборі жінки спілкувалися між собою за національним принципом, складалися групи українок, білорусок, росіянок $[31,35]$. Згідно зі спогадами 
іншої жінки, у таборі створювалися маленькі групи, які здебільшого мали схожі характери, звички чи просто симпатії [25, 75].

Жінки допомагали одна одній не лише морально. Як зазначає колишня «алжирка», у таборах жінки ділилися всім, чим могли, аж до часточки часнику [21, 173]. Якщо у жінок була можливість десь за межами зони дістати їжу, то вони намагалися пронести їі до табору, щоб нагодувати інших $[25,76]$. Галина Семьонова, працюючи головним інженером і маючи пропуск за межі табору, намагалася передавати листи родичам ув'язнених, а також проносити їжу до табору [16, 375]. Людмила Грановська 3 табору в Мордовії згадувала, що жінки настільки заприятелювали, що коли їх почали перерозподіляти, не обійшлося без драматичних сцен: «Деякі жінки так здружилися, що розлучення доводило їх до запаморочення. Наші конвоїри буквально відривали жінок одну від одної» [7, 187].

У таборах ГУЛАГу для коригування вільного часу ув'язнених існувала Культурно-виховна частина (далі - КВЧ) (табірна установа, що контролювала вільний час). Як одна 3 основних складових табірного життя в'язнів, згідно зі своїм призначенням, вона не мала на меті розважити та покращити життя ув'язнених, бо займалася «перевихованням» в'язнів через пропаганду переваг радянського державного устрою, а також повинна була стимулювати арештантів до праці $[33,228]$. КВЧ могла проводити в таборах такі виховні заходи: олімпіади, виїзди культбригад, демонстрації кінофільмів та їх подальше обговорення, виробничі змагання, спортивні змагання і танцювальні вечори, концерти художньої самодіяльності, драматичні гуртки, групові читання, лекції та політичні бесіди [6, 32, 33].

У АЛЖИРі не було Культурно-виховної частини, як в інших гулагівських таборах. Жінки були позбавлені будь-якого організаційного дозвілля, часточки духовного життя [25,73] (хоча, за словами колишньої ув'язненої, табірне керівництво один раз на місяць показувало жінкам кінофільм $[21,173])$. На відміну від жінок-арештантів табору для членів сім’і «зрадників Батьківщини» в Мордовії, «алжирки» не мали навіть радіо [7, 196; $31,40]$. Зазначимо, що різниці між статусом ув'язнених двох таборів не було. Фактично дружинам «ворогів народу» просто пощастило з радіо. Людмила Грановська пам'ятає історію, як воно опинилося в таборі: «Одного разу у таборі відчинилися величезні ворота $i$ заїхав віз із їжею для їдальні. У віз була запряжена коняка, а за нею плилося лоша. Грузинки як побачили так $i$ почали плакати, рвати волосся на собі, битися головами об стіни. "Де наші діти? Що з ними?» За грузинками почали ридати і всі інші, а було нас тисяч n'ять. Прибігло керівництво. Почали загрожувати... Обіцяли дозволити писати листи дітям, обіияли роботу, щяоб ми від нудоти не зійшли з розуму. На наступний день було привезено радіо до табору» [7, 196]. Тож, швидше за все, його не повинно бути й у Мордовському таборі, бо цього взагалі не передбачалося для дружин «зрадників Батьківщини». 
Зважаючи на високоосвічений контингент Акмолінського спецвідділення, жінки в таборі постійно намагалися знайти час i можливість для культурного відпочинку. Через те, що основною функцією КВЧ було «перевиховання» ув'язнених ГУЛАГу, табірне керівництво не дуже переймалося тим, як проводять свій вільний час арештанти. По-перше, як уже згадувалося, у таборі не було самої КВЧ. По-друге, жінки вважалися «соціально-небезпечним» контингентом, який перевиховати було неможливо, бо вони «зрадили Батьківщину» [20, 163].

Жінки-ув'язнені самі організовували своє культурне дозвілля у вільний час. Здебільшого, вони проводили концерти та літературні вечори. За спогадами арештанта, у бараці для жінок була одна маленька радість: концерт самодіяльності [22, 79]. Дочка колишньої ув'язненої пам'ятає 3 розповідей матері, що концерти були дуже цікавими $[18,117]$. Галина Степанова-Ключникова у своїх спогадах пише, що відома ленінградська артистка зібрала 3 «алжирок» чудовий хор, який мав яскравий репертуар: Штраус, Оффенбах, Чайковський, арії з різних опер, відомі романси $[31,40]$.

Культурна самодіяльність жінок в АЛЖИРі була одним зі способів відволікти себе від утоми після робочого дня, від усвідомлення того, що ти перебуваєш за колючим дротом далеко від своєї родини, далеко від нормального життя. Олена Мамаева згадує: «Усі ми сидимо чи лежимо на нарах, а поміж нами, посередині бараку, виступають артистки, яких у таборі налічувалося багато. Від гарного виконання пісень, таниів, хорового співу, які мені здавалися чудовими, надовго зберігся приємний, теплий спогад. Здавалося щзо зранку наступного дня всі підіймалися на роботу веселіше» $[22,79]$.

Літературні вечори відбувалися майже кожен день. На них жінки розповідали здебільшого романи. Через те, що в таборі зовсім не було книжок, жінки читали все напам'ять. Виходило кожен вечір по одній главі. За словами колишньої жінки-арештанта, кожен вечір у бараці жінки сідали навколо оповідачки та завмирали в тиші, стававши свідками феноменальної людської пам'яті [31, 40].

Одним із видів культурного дозвілля в жіночому таборі був танцювальний гурток. Колишня арештант розповідала, що вони відбувалися після робочого дня в бані й під час самого заняття: «Заморені за день жінки ніби знову оживали» $[3,13]$.

Аби розбавити сіре гулагівське повсякдення, жінки також займалися оздобленням табірного інтер'єру. Зі згадок Марії Данилеко, професійні митці 3 Ленінградської академії дуже гарно розмалювали табірну їдальню, а найцікавіше те, що фарбу вони виварювали із жіночої спідньої білизни $[8,83]$.

Цікаво ставилися «алжирки» до радянських свят. Загалом у таборах, особливо для «політичних» злочинців, визначні дати історії Радянського Союзу не святкувалися. Можна припустити, що «алжирки» як «соціальнонебезпечні» були не гідними святкування визначних дат радянської історії. 
Наприклад, Першого травня чи Сьомого листопада жінок замикали в бараках і не дозволяли виходити. Галина Степанова-Ключникова зазначала, що ці дні святкувало табірне керівництво $[31,40]$. Олена Мамаєва зауважувала, що в дні великих свят, особливо на свято річниці Великої Жовтневої революції, важко було пережити те, що ти позбавлений волі $[22,79]$. Одразу жінки згадували, як проходив цей день на волі, коли вони були зі своєю родиною $[22,79]$. Натомість Сарра Наумова згадувала, що, коли вона була в АЛЖИРі, усі радянські свята, і навіть Великий Жовтень, перестали сприйматися нею як визначні дати і в іï пам'яті на той час залишилися лише дати народження іiі дітей $[24,23]$. А за словами Ганни Ларіної, яка відбувала покарання як дружина «зрадника Батьківщини» у таборі біля м. Томськ, свят вони чекали, тому що ходили чутки, що до великих радянських свят або до днів народження Сталіна буде амністія [20, 15].

Зазвичай у ГУЛАГівських таборах (жіночого, але з різним контингентом ув'язнених, або ж змішаного типу), перед арештантами часто стояло питання: як залишитися людиною в табірному просторі, зважаючи на знущання табірних працівників, постійний голод, важку працю, присутність «криміналітету», який своєю аморальною поведінкою робив із табірного повсякдення пекло. Як випливає з нашого дослідження, перед «алжирками» це питання стояло не так гостро.

На основі спогади колишніх жінок-арештантів, констатуємо, що «алжирки» відрізнялися від інших ув'язнених ГУЛАГу. Вони відбували покарання в іншому - специфічному, закритому табірному просторі, де зосередилися лише такі як вони, члени сім'ї «зрадника Батьківщини», дружини «ворогів народу». Жінки безмежно вірили в справедливість радянського керівництва та на початку свого арешту чекали на швидке звільнення, коли буде викрито винних жінок і їхніх чоловіків звільнять. Така віра в партію та у свою майбутню свободу, можливо, допомогла жінкам пройти свій термін ув'язнення. Вони постійно сподівалися й мали надію та ентузіазм.

Попри те, що табори системи ГУЛАГ відрізнялися один від одного, у них було щось спільне, притаманне їм усім. Якщо говорити про Акмолінське спецвідділення, то воно не схоже на жоден із таборів. До праці, на відміну від інших ув'язнених ГУЛАГу, жінки ставилися дуже серйозно. Праця для арештанток була способом самоствердження. Таким способом вони доводили й собі, і табірному керівництву те, що вони громадяни своєї держави, які продовжують віддано служити ій, що вони не $\epsilon$ «зрадниками» i не $\epsilon$ «політичними злочинцями», що все це непорозуміння. Вони вважали, що за відповідальну працю, їх звільнять і можливо повернуть «чесне ім'я», і не лише їм, але і їхнім чоловікам. Праця допомагала відволіктися від горя, від того, що в жінок відібрали дітей, родину. Не менш вагомим було й підтримання дружніх відносин, які допомагали відчути, що ти комусь потрібен, і хтось потребує тебе й твоєї уваги. 
Те, що в АЛЖИРі не було Культурно-виховної частини, можна пояснити по-різному. 3 одного боку, зважаючи на те, що табір існував недовго й починався 3 нічого, можна припустити, що керівництво ГУЛАГу просто не встигло розбудувати там Культурно-виховну частину. Але 3 іншого, керівництво ГУЛАГу взагалі не вважало за необхідне організовувати культурний бік життя жінок. Воно ніби їх викреслило з життя: навіть не намагалися (хоч це було формально записано на папері) «перевиховати», як усіх інших ув'язнених ГУЛАГу. Тому жінки самі організовували своє дозвілля. Із проаналізованих спогадів робимо висновок, що табірне керівництво було не проти самостійної організації дозвілля жінками. Культурна самодіяльність, як уже згаданий спосіб виживання, все ж таки допомагала відволіктися від суму, стала для жінок способом самовираження, а також можливістю займатися тим, що їх цікавило, підіймало настрій і покращувало умови табірного повсякдення.

Проведений нами аналіз дає змогу зрозуміти, що Акмолінське відділення було одним із тих феноменів ГУЛАГу, який і досі не $є$ розкритим повністю. Опрацювання в подальшому названої тематики $є$ перспективним із декількох причин. Дослідження повсякденності жінок-арештантів $\epsilon$ нагальним 3 огляду на важливість достовірності історії розвитку нашої країни, адже спостерігається недостатня іiі розробленість в українській науці. Зацікавленість саме жіночим виміром таборового повсякдення, поза сумнівом, $\epsilon$ виправданою, адже наразі гендерним аспектам цієї тематики приділяють мало уваги. На нашу думку, аналіз табірного досвіду є важливим для осмислення морального досвіду минулих поколінь, які пройшли сталінські табори, особливо для формування основних компетентностей, зокрема громадянської, у представників, зокрема, української нації. Вивчення, усвідомлення й урахування табірного досвіду саме українців одна з основних складових подолання наслідків тоталітарної спадщини. Це $\epsilon$ невід'ємним чинником для формування історичної пам'яті нашого суспільства та для розуміння того, що таких сторінок більше не має бути на шпальтах історії України.

\section{Abstract}

The main task of the author is an attempt to show the specificity of everyday life of the women-prisoners of Akmolinsk camp for the wives of «traitors of the Motherland», emphasizing the ways of survival of the prisoners and forms of overcoming their grief in the camp. Fundamentally in the methodological base of research there are general scientific principles of analysis and synthesis, the method of critical analysis of sources, the methodology of everyday history, as well as the methodology of working with ego-documents. In the article, the author used the anthropocentric approach according to which the main object of study is a person, as well as the gender approach to analyze the actual female dimension of everyday life in camps. 
Akmolinsk camp differed not only from other correctional labor camps of the GULAG system, but also from similar ones. Women had their own value system there and tried to survive behind barbed wire in a different way. Their daily condemnation was assisted by daily work and faith in the future, namely, the quickest release. And in order to survive the grief from the loss of the family and friends, creativity and friendship with each other helped.

This topic in the future can be used to compare the everyday life of women in different periods of the existence of a corrective labor system. In the future, the results of the research may be useful for a more profound analysis of the camp experience of Ukrainian women. In general, the expansion and further analysis of this topic is important for the formation of historical memory in Ukraine and the overcoming of the totalitarian past.

Key words: GULAG, women's history, history of everyday life, member of the family of «traitor of the motherland», «enemy of the people», Akmolinsk camp for the wives of the traitors of the Motherland.

\section{Аннотация}

Главной задачей автора является попьтка показать специфику повседневной жизни женщин-заключенных Акмолинского лагеря для жен «изменников Родиныл», акиентируя внимание на способах выживания арестанток и на формах преодоления горя в лагере. В основе методологической базы исследования - общенаучные принщипь анализа и синтеза, метод критического анализа источников, методология повседневной истории, а также методика работы с еgо-документами. В данной статье автором были использованы: антропоцентрический подход, согласно которому основным объектом изучения является человек, а также гендерный подход для анализа конкретно женского опыта повседневной жизни в лагерях.

Акмолинский лагерь отличался не только от других исправительнотрудовых лагерей системы ГУЛАГ, но и от себе подобных. Там женщины создали свою систему ценностей и по-своему пытались выжить за колючей проволокой. Выдержать осуждение им помогал ежедневный труд и вера в будущее, а именно в скорейшее освобождение. А для того, чтобы пережить горе от потери семьи и своих близких, женщинам помогали творчество и дружба.

Данная тематика в будущем может быть использована для сравнения повседневной жизни в разный период существования исправительнотрудовой системы. В будущем, результаты исследования могут быть полезными для более глубокого анализа лагерного опыта именно украинских женшин. Расширение и последуюший анализ данного исследования важны для формирования в Украине исторической памяти и преодоления ее тоталитарного прошлого. 
Ключевые слова: ГУЛАГ, женская история, история повседневности, член семьи «изменника Родиныл", «враг народа», Акмолинский лагерь для жен изменников Родины.

\section{ДЖЕРЕЛА ТА ЛІТЕРАТУРА}

1. Адамова-Слизорберг О. Л. Путь. Москва : Возвращение, 1993. 254 с.

2. Анцис М. Л. Спецотделение № 17. URL: http://www.sakharov-center.ru/ museum/library/unpublished/?t=anzis (дата звернення 11.03.2018).

3. Афонина Т.П. Воспоминания узниц АЛЖИРа. Малиновские вехи: Сб. публикачий и воспоминаний (от АЛЖИРа до современной Малиновки). Малиновка; Астана, 2003. С. 13-14.

4. Бушуева 3. М. Воспоминания. Годы террора: Книга памяти жертв политических репрессий. Пермь : Изд-во «Здравствуй», 1998. С. 116-123.

5. Вронська Т. В. Упокорення страхом: сімейне заручництво у каральній політиці радянської влади (1917-1953рр.): Наукове видання. Київ : Темпора, 2013. $624 \mathrm{c}$.

6. Гапак М. В. На небезпечній службі в ГУЛАГу. Ужгород : Патент, 1999. $149 \mathrm{c}$.

7. Грановская Л. И. Арест. Нева. 1991. № 9. С. 193-198.

8. Даниленко М. Л. Стерегли нас как золото, а ценили как г... Cттраницы трагических судеб: Сб. Воспоминаний жертв полит. репрессий в СССР в 1920-1950-е г2. Алматы : Жеті жаргы, 2002. С. 19-85.

9. Добровольский И. В. ГУЛАГ: его стоители, обитатели и герои. Франкфурт/Майн; Москва, 1999. 453 с.

10. Дьяков Б. А. Повесть о пережитом. Москва: Сов. Россия, 1966. 264 с.

11. Елеуханова С. В. История Карлага: охрана, режим и условия содержания заключенных (1930-1956 гг.): автореф. дисс. ... к-та ист. наук: Караганда, 2009. URL: http://avtoreferats.com/article/view/id/15779 (дата звернення: 28.03.2018).

12. Иванова Г. М. История ГУЛАГа, 1918-1958: социально-экономический и политико-правовой аспекты. Москва : Наука, 2006. 438 с.

13. Игнаткин Ю. А. Рассказ из 1937. Малиновские вехи: Сб. публикаций и воспоминаний (от АЛЖИРа до современной Малиновки). Малиновка; Астана, 2003. С. 25-45.

14. Ким Ю. Ч., Ким А. Ч. О нашей маме Нине Всесвятской, учительнице. Очерки, воспоминания, материалы из домашнего архива. Москва : Общество «Мемориал»; Изд-во «Звенья», 2007. 255 с.

15. Кісь О.Р. Українки в ГУЛАГу: вижити значить перемогти. Львів : Інститут народознавства НАН України, 2017. 288 с.

16. Китаева Л. А. О моих родителях. ГУЛАГ: его строители, обитатели и герои. Франкфурт / Майн, Москва, 1999. С. 372-376. 
17. Колдомасова Г. В. В те далекие годы. Малиновские вехи: Сб. публикаций и воспоминаний (от АЛЖИРа до современной Малиновки). Малиновка; Астана, 2003. С. 15-24.

18. Косталевская Т. В. Воспоминания. Вся наша жизнь: Воспоминания Галины Ивановны Левинсон и рассказы записанные ею. Москва: «Мемориал», 1996. С. 114-127.

19. Кучумова O. М. Жены. URL: http://www.sakharov-center.ru/asfcd/auth/ $? \mathrm{t}=$ page\&num $=6279$ (дата звернення 12.04.2018).

20. Ларина А. М. Незабываемое. Москва : Изд-во АПН, 1989. 365 с.

21. Майжолова-Куленова В. Бывает радость и в тяжелые дни // Страницы трагических судеб: Сб. Воспоминаний жертв политических репрессий в СССР в 1920-1950-е гг. Алматы : Жеті жаргы, 2002. С. 169-174.

22. Мамаева Е. А. Жизни прожить. Москва : Копи-центр, 1998149 с.

23. Мы будем жить. Документальный фильм / Реж. С. Павловский, Д. Виолина. Республика Казахстан. 2009.

24. Наумов А. История одного детства. История. 2001. Вип. 28. С. 1-9.

25. Поль И. Л. Оглянись со скорбью: История одной семьи. Иркутск : Сиб. кн. изд-во, 1991. 192 с.

26. Рогинский А. Б., Даниэль А. Ю. Аресту подлежат жены. URL: http://polit.ru/ article/2003/10/30/628134/ (дата звернення 15.03.2018).

27. Рыскулова С. Т. Аиза - жена Турара Рыскулова. Страницы трагических судеб: Сб. Воспоминаний жертв полит. репрессий в СССР в 1920-1950-е г2. Алматы: Жеті жаргы, 2002. С. 222-227.

28. Салтык Г. А. Воспоминания бывших узников исправительно-трудовых лагерей CCCP как исторический источник. URL: https://cyberleninka.ru/ article/v/vospominaniya-byvshih-uznikov-ispravitelno-trudovyh-lagerey-sssr-kakistoricheskiy-istochnik (дата звернення 15.03.2018).

29. Славина И. И. Тоненький нерв истории. URL: http://www.sakharovcenter.ru/asfcd/auth/?t=page\&num=13089 (дата звернення 16.03.2018).

30. Солженицын А. И. Архипелаг Гулаг. Москва : ИНКОМ МВ, 1991. Т. 6. $432 \mathrm{c}$.

31. Степанова-Ключникова Г. Е. Казахстанский АЛЖИР. Москва, Малиновка, Астана : Ассоциация жертв незаконных полит. репрессий, 2003. 62 с.

32. Шумяцкая O. Главный уговор - не разреветься. URL: http:// www.novayagazeta.ru/arts/42885.html (дата звернення 13.03.2018).

33. Эпплбаум Э. ГУЛАГ. Паутина Большого террора. Москва : Моск. школа полит. исследований, 2006. 608 с.

\section{References}

1. Adamova-Slizorberg, O. L. (1993). Put [The Way]. Moskva : Vozvrashchenie.

2. Antsis, M. L. Spetsotdelenie № 17 [Special Department]. URL: http:// www.sakharov-center.ru/museum/library/unpublished/?t=anzis 
3. Afonina, T. P. (2003). Vospominaniya uznits ALZhIRa. Malinovskie vekhi: Sb. publikatsiy i vospominaniy (ot ALZhIRa do sovremennoy Malinovki) [Memoirs of the Prisoners of ALZHIR. The Collection of Publications and Memoirs (from ALZHIR to modern Malinovka)]. Malinovka; Astana, 13-14.

4. Bushueva, Z. M. (1998). Vospominaniya. Gody terrora: Kniga pamyati zhertv politicheskikh repressiy [Memories. Years of Terror: A Book of Memory of Victims of Political Repressions]. Perm : Izd-vo «Zdravstvuy», 1S. 16-123.

5. Vronska, T. V. (2013). Upokorennia strakhom: simeine zaruchnytstvo u karalnii politytsi radianskoi vlady (1917-1953 rr.): Naukove vydannia [Frustrated by Fear: Family Hostage-Taking in the Punitive Policy of Soviet Power (1917-1953): Scientific publication]. Kyiv : Tempora.

6. Hapak, M. V. (1999). Na nebezpechnii sluzhbi v HULAHu [At the Dangerous Service at the GULAG]. Uzhhorod : Patent.

7. Granovskaya, L. I. (1991). Arest [Arrest]. Neva, 9, 193-198.

8. Danilenko, M. L. (2002). Steregli nas kak zoloto, a tsenili kak g... Stranitsy tragicheskikh sudeb: Sb. Vospominaniy zhertv polit. repressiy v SSSR v 1920-1950-e gg [We Were Guarded as Gold, and Appreciated as Shit. Pages of Tragic Destinies: The collection of Memoirs of Victims of Political Repressions in the USSR in the 1920s-1950s]. Almaty : Zheti zhargy, 19-85.

9. Dobrovolskiy, I. V. (1999). GULAG: ego stoiteli, obitateli i geroi [GULAG: Its Builders, Inhabitants and Heroes]. Frankfurt/Mayn; Moskva.

10. Dyakov, B. A. (1966). Povest o perezhitom [A Tale of Life]. Moskva: Sov. Rossiya.

11. Yeleukhanova, S. V. (2009.) Istoriya Karlaga: okhrana, rezhim i usloviya soderzhaniya zaklyuchennykh (1930-1956 gg.) [History of the Karlag: Protection, Regime and Conditions of Detention of Prisoners]. (Abstract of $\mathrm{PhD}$ thesis), Karaganda. URL: http://avtoreferats.com/article/view/id/15779

12. Ivanova, G. M. (2006). Istoriya GULAGa, 1918-1958: sotsialno-ekonomicheskiy i politiko-pravovoy aspekty [History of the GULAG, 1918-1958: SocioEconomic and Political-Legal Aspects]. Moskva : Nauka.

13. Ignatkin Yu. A. (2003). Rasskaz iz 1937. Malinovskie vehi: Sb. publikatsiy i vospominaniy (ot ALZhIRa do sovremennoy Malinovki) [Story from 1937. The Collection of Publications and Memoirs (from ALZHIR to modern Malinovka)]. Malinovka; Astana, 25-45.

14. Kim, Yu. Ch., Kim, A. Ch. (2007). O nashey mame Nine Vsesvyatskoy, uchitelnitse. Ocherki, vospominaniya, materialy iz domashnego arkhiva [About our mother Nina Vsesvyatskaya, a Teacher. Essays, Memoirs, Materials from the Home Archive]. Moskva : Obshchestvo «Memorial»; Izd-vo «Zvenya».

15. Kis O. R. (2017). Ukrainky v HULAHu: vyzhyty znachyt peremohty [Ukrainian women in the GULAG: the victory of survival]. Lviv: Instytut narodoznavstva NAN Ukrainy. 
16. Kitaeva, L. A. (1999). O moikh roditelyak. GULAG: ego stroiteli, obitateli i geroi [About My Parents. GULAG: Its Builders, Inhabitants and Heroes]. Frankfurt/Mayn, Moskva, 372-376.

17. Koldomasova G. V. (2003). V te dalekie godyi. Malinovskie vehi: Sb. publikatsiy i vospominaniy (ot ALZhIRa do sovremennoy Malinovki) [In those early years. The Collection of Publications and Memoirs (from ALZHIR to modern Malinovka)]. Malinovka; Astana, 15-24.

18. Kostalevskaya, T. V. (1996). Vospominaniya. Vsya nasha zhizn: Vospominaniya Galiny Ivanovny Levinson i rasskazy zapisannye eyu [Memories. Our whole life: Memories of Galina Ivanovna Levinson and Stories Recorded by Her]. Moskva : «Memorial», 114-127.

19. Kuchumova, O. M. Zheny [The Wives]. URL: http://www.sakharov-center.ru/ asfcd/auth/?t=page\&num $=6279$

20. Larina, A. M. (1989). Nezabyvaemoe [Unforgettable]. Moskva : Izd-vo APN.

21. Mayzholova-Kulenova, V. (2002). Byvaet radost i v tyazhelye dni. Stranitsy tragicheskikh sudeb: Sb. Vospominaniy zhertv politicheskikh repressiy v SSSR v 1920-1950-e gg [Sometimes There Is Joy in Bad Days. Pages of Tragic Destinies: The collection of Memoirs of Victims of Political Repressions in the USSR in the 1920s-1950s]. Almaty : Zheti zhargy, 169-174.

22. Mamaeva, Ye. A. (1998). Zhizni prozhit [Lives to Live]. Moskva : Kopi-tsentr.

23. Pavlovskiy S., Violina D. (2009). My budem zhit. Dokumentalnyy film [We will live. Documentary]. Respublika Kazakhstan.

24. Naumov, A. (2001). Istoriya odnogo detstva [The History of One Childhood]. Istoriya, 28, 1-9.

25. Pol, I. L. (1991). Oglyanis so skorbyu: Istoriya odnoy semi [Look Around with Sorrow: The History of One Family]. Irkutsk : Sib. kn. izd-vo.

26. Roginskiy, A. B., Daniel, A. Yu. Arestu podlezhat zheny [The Wives Are to Be Arrested]. URL: http://polit.ru/article/2003/10/30/628134/

27. Ryskulova, S. T. (2002). Aiza - zhena Turara Ryskulova. Stranitsy tragicheskikh sudeb: Sb. Vospominaniy zhertv polit. repressiy v SSSR v 1920-1950-e gg [Aisa is the Wife of Turar Ryskulov. Pages of Tragic Destinies: The collection of Memoirs of Victims of Political Repressions in the USSR in the 1920s-1950s]. Almaty : Zheti zhargy, 222-227.

28. Saltyk, G. A. Vospominaniya byvshikh uznikov ispravitelno-trudovykh lagerey SSSR kak istoricheskiy istochnik [Memoirs of Former Prisoners of the Forced Labor Camps of the USSR as a Historical Source]. URL: https://cyberleninka.ru/article/v/vospominaniya-byvshih-uznikov-ispravitelnotrudovyh-lagerey-sssr-kak-istoricheskiy-istochnik

29. Slavina I. I. Tonenkiy nerv istorii [Thin nerve of history]. URL: http://www.sakharov-center.ru/asfcd/auth/?t=page\&num=13089

30. Solzhenitsyn, A. I. (1991). Arkhipelag Gulag [The Gulag Archipelago]. Moskva : INKOM MV, Vol. 6. 
31. Stepanova-Klyuchnikova, G. Ye. (2003). Kazakhstanskiy ALZhIR [Kazakhstan ALZHIR]. Moskva, Malinovka, Astana: Assotsiatsiya zhertv nezakonnykh polit. repressiy.

32. Shumyatskaya, O. Glavnyy ugovor - ne razrevetsya [The Main Agreement Is Not to Burst into Tears]. URL: http://www.novayagazeta.ru/arts/42885.html

33. Epplbaum, E. (2006). GULAG. Pautina Bolshogo terrora [Gulag: A History]. Moskva : Mosk. shkola polit. issledovaniy.

УДК 351.853-025

\section{ГРОМАДСЬКИЙ КОНТРОЛЬ ДІЯЛЬНОСТІ ПІДПРИЕМСТВ ТОРГІВЛІ, ХАРЧУВАННЯ ТА ПОБУТОВОГО ОБСЛУГОВУВАННЯ: ДЕТАЛІ ПОЛІТИЧНОЇ РЕКОНСТРУКЦІЇ «ВІДЛИГИ»}

\section{Докашенко Віктор}

У статті розглядаються політичні аспекти сочіальних трансформацій епохи «відлиги». У форматі дискусії доводиться, щңо проблемний розвиток соиіальної сфери в республіиі обумовлювався пріоритетним розвитком виробництва групи «А» перед групою «Б», що первісно зумовлювало їх нерівноправне становище $i$ викликало запрограмоване відставання останньої. Доводиться, щчо пильна увага нової влади до питань сочіальної сфери була продиктована як загостренням політичного протистояння з прихильниками сталінського режиму, так і необхідністю пристосування політичної системи СРСР до умов повоєнного світу. Прочес формування професійними спілками громадського контролю розподіляється дослідником на два етапи. Підкреслюється, що партією було спеціально обрано такий предмет політичного впливу, який міг принести максимальні політичні дивіденди у вигляді підтримки з боку широких верств населення. Це були підприємства торгівлі, громадського харчування та побутового обслуговування населення. Слабко розвинені, вони не могли задовольнити потреб суспільства, а тому найменші позитивні зрушення у иій царині, ставилися владі в заслугу. Зроблено декілька принципових висновків щодо значення громадського контролю. Зокрема стверджується, щзо приведення його в дію значною мірою зумовлювалося необхідністю маскування концептуальних хиб, покладених в основу радянської економіки, а також потребою камуфлювання тоталітарної сутності нової влади, що породжувало ілюзію ї̈ турботи про суспільство. Автор припускається думки, що організований профспілками контроль за сферою торгівлі, харчування та побуту дав змогу зрушити проблему з місия, щзо на певний час $і$ відтермінувало неминучу відставку влади «відлиги». Разом з тим, дослідник наголошує, щя організований 